\title{
Residual stress management: recent advances in engineering methods for non-destructive measurement and beneficial redistribution of residual stresses
}

\author{
Kontrolisanje zaostalih napona: razvoj najnovijih inženjerskih \\ metoda za merenje bez razaranja i povoljnu preraspodelu zaostalih \\ napona
}

\begin{abstract}
Stručni rad / Professional paper
Rad je u izvornom obliku objavljen u okviru 72. IIW godišnje Skupštine $i$ međunarodne konferencije održane u BratislaviSlovačka 07-12. Jula 2019

Rad primljen / Paper received:

Decembar 2020.
\end{abstract}

Prevod izvornog rada na srpski jezik: S.A. Sedmak

Keywords: Residual stress management, ultrasonic peening, non-destructive ultrasonic measurement of stresses, ultrasonic impact treatment, residual stres

\begin{abstract}
Welding is used widely in the automotive industry for joining a variety of structural components and parts. Of paramount importance in these structures are their engineering properties, such as fatigue life, distortions, dimensional stability and corrosion resistance that can be affected considerably by the presence of residual stresses (RS). The knowledge of RS and the ability to control their distribution in welded structures is critical when evaluating their fatigue life and preventing catastrophic failures. An engineering concept of residual stress management (RSM) has been developed that addresses all aspects of residual stresses in structural elements. RSM includes three major stages in stress management, i.e. RS determination, RS analysis and RS redistribution. Using this approach, stresses in structures and materials can be evaluated in each specific case either theoretically or experimentally and the performance and fatigue behavior of such structures optimized. This paper is built as an overview of the RSM concept and its application in the fields of non-destructive measurement of residual and applied stresses and in treatment of structures with residual stresses to achieve better performance and longer fatigue life. All three stages of the RSM concept will be discussed and for each of the stages practical engineering approach examples will be given. An example of a project in
\end{abstract}

Adresa autora / Author's address:

Structural Integrity Technologies, Inc., Markham, Canada

Jkleiman@sintec.ca

Ključne reči: Kontrolisanje zaostalih napona, ultrazvučno sačmarenje, ultrazvučno merenje napona bez razaranja, obrada ultrazvučnim udarom, zaostali napon

\section{Rezime}

Zavarivanje je veoma rasprostranjeno $u$ automobilskoj industriji i koristi se za spajanje raznih vrsta komponenata i delova. Inženjerske osobine ovih konstrukcija su od ključne važnosti, uključujući zamorini vek, distorzije, stabilnost dimenzija i otpornost na koroziju, pri čemu na sve ove faktore može značajno uticati prisustvo zaostalih napona (ZN). Poznavanje zaostalih napona i mogućnost kontrole njihove raspodele $u$ zavarenim konstrukcijama je od ključnog značaja pri oceni zamornog veka i sprečavanju katastrofalnih otkaza. Inženjerski koncept kontrolisanja zaostalih napona (Residual stress management - RSM) je razvijen sa ciljem da odgovori na sve aspekte zaostalih napona $u$ nosećim elementima. RSM obuhvata tri glavne faze kontrole napona, tj. određivanje ZN, njihovu analizu i preraspodelu. Primenom ovog pristupa, naponi $u$ konstrukcijama i materijalima se mogu oceniti za svaki zaseban slučaj, kako teorijski takoi eksperimentalno, na osnovu čega se performance i ponašanje pri zamoru ovakvih konstrukcija može optimizovati. Ovaj rad je napisan kao pregled koncepta RSM i njegove primene u oblastima merenja bez razaranja zaostalih i delujućih napona i poboljšavanju performansi i produženju zamornog veka konstrukcija u kojima su ovakvi naponi prisutni. Sve tri faze koncepta RSM će biti razmotrene i za svaku od njih će biti predstavljen 
which the residual stress distribution in a filet welded joint was measured, analyzed and changed by post-weld treatment will be presented to demonstrate the effectiveness of the RSM approach. The advancements in the modern tools used in this project for non-destructive measurement of residual stresses using an ultrasonic computerized complex for residual stress measurement and the ultrasonic peening for redistribution of the residual stresses that allowed improving the quality of the welds and increasing their fatigue life will also be presented.

\section{Introduction}

Residual stress can significantly affect engineering properties of materials and structural components, notably, fatigue life, distortion, dimensional stability, corrosion resistance etc.. Such effects usually lead to considerable expenditures in repairs and restoration of parts, equipment and structures. For that reason, the residual stress analysis is a compulsory stage in the design of structural elements and in the estimation of their reliability under real service conditions.

Systematic studies had shown that welding residual stresses may lead to a drastic reduction in fatigue strength of welded elements. In multi-cycle fatigue ( $\mathrm{N}>106$ cycles) the effect of residual stresses can be compared with the effect of stress concentration. Even more significant are the effects of residual stresses on the fatigue life of welded elements in the case of relieving harmful tensile residual stresses and introducing beneficial compressive residual stresses in the weld toe zones. The results of fatigue testing of welded specimens in as-welded condition and after application of ultrasonic peening showed that in case of non-load caring fillet welded joint in high strength steel, the redistribution of residual stresses resulted in approximately two-fold increase in the limit stress range [1,2].

The residual stresses, therefore, are one of the main factors determining the engineering properties of materials, parts and welded elements and this factor should be taken into account during the design and manufacturing of different products. Although certain progress has been achieved in the development of techniques for residual stress management, a considerable effort is still required to develop efficient and cost-effective methods of residual stress measurement and analysis as well odgovarajući praktični inženjerski pristup kao primer. Jedan takav primer obuhvata raspodelu zaostalih napona u ugaonom zavarenom spoju, koji su određeni, analizirani i izmenjeni primenom naknadne termičke obrade. Ovaj primer će demonstrirati efikasnost RSM pristupa. Takođe će biti prikazana i dostignuća u izradi modernih alata koji će se koristiti u ovom projektu za merenje bez razaranja zaostalih napona, primenom ultrazvučnog kompjuterizovanog kompleksa i ultrazvučnog "sačmarenja" u preraspodeli zaostalih napona kojom se positže poboljšani kvalitet zavarenih spojeva i povećan zamorni vek.

\section{Uvod}

Zaostali naponi mogu značajno uticati na ponašanje materijala i komponenti konstrukcije, pre svega na zamorni, vek, distorziju, stabilnost dimenzija, otpornost na koroziju, itd. Ovakvi uticaji obično za rezultat imaju značajne troškove reparature i obnove delova, opreme i konstrukcija i iz tog razloga, analiza zaostalih napona predstavlja obavezan deo faze konstruisanja nosećih elemenata i ocene njihove pouzdanosti u stvarnim radnim uslovima.

Sistematske studije su pokazale da zaostali naponi pri zavarivanju mogu doprineti znajačnom umanjenju zamorne čvrstoće zavarenih elemenata. Prvi visokocikličnom zamoru ( $N>10^{6}$ ciklusa), efekat zaostalih napona se može uporediti sa efektom koncentracije napona. Zaostali naponi mogu imati još veći uticaj na zamorni vek zavarenih elemenata u slučaju njihovog otpuštanja i uvođenja pozitivnih prisitnih zaostalih napona u zavarenom spoju. Rezultati ispitivanja zamora zavarenih spojeva $u$ početnom stanju i nakon primene ultrazvučnog sačmarenja su pokazali da je, u slučaju ne nosećih ugaonih spojeva od čelika povišene čvrstoće, preraspodela zaostalih napona dovela do približno dvostrkog povećanja graničnog napona $[1,2]$.

Stoga, zaostali naponi predstavljaju jedan od glavnih faktora koji određuje inženjerske osobine materijala, delova i zavarenih konstrukcija, koji se mora uzeti u obzir tokom projektovanja različitih proizvoda. lako je ostvaren izvestan napredak u razvoju tehnika za kontrolu zaostalih napona, još uvek je potreban značajan napor kako bi se razvila efikasna i isplativa metoda merenja zaostalih napona, kao i tehnologije za povoljnu preraspodelu zaostalih napona. 
as technologies for the beneficial redistribution of residual stresses.

It is very important to consider the problem of residual stress as a complex problem including, at least, stages of the determination, the analysis and the beneficial redistribution of residual stresses. The combined consideration of the abovementioned stages of residual stress analysis gives rise to so called Residual Stress Management (RSM) concept approach [3]. The RSM concept includes the following main stages:

Stage 1: Residual Stress Determination.

Stage 2: Analysis of the Residual Stress Effects. The effect of residual stresses can be evaluated either through experimental studies or via computational methods.

Stage 3: Residual Stress Modification, if required. The modification of the residual stresses could be performed through changes in the technology of manufacturing/assembly and/or through application of stresses relieving techniques.

A number of new advanced engineering tools for all three stages of RSM were developed recently at Structural Integrity Technologies (Sintec) Inc. (Markham, Canada). An overview of the newest developments of these engineering tools for residual stress management and examples of their practical application are presented below.

\section{Residual stress determination}

The stresses can be evaluated directly through measurements either using destructive methods or nondestructive methods and through computation. Over the last few decades, various destructive and non-destructive quantitative and qualitative methods of residual stress measurement have been developed [4]. In general, a distinction is usually made between destructive and nondestructive techniques.

The first series of methods is based on destruction of the state of equilibrium of the residual stress after sectioning of the specimen, machining, layer removal or hole drilling. The redistribution of the internal forces leads to local strains, which are measured to evaluate the residual stress field. The residual stress is deduced from the measured strain using the elastic theory (analytical approach or finite element calculations).

The second series of methods is based on nondestructive measurements of residual stresses that are based on the relationship between the physical and the crystallographic parameters and the
Jako je bitno posmatrati zaostale napone kao složen problem, koji minimalno obuhvata faze njihovog određivanja, analizu i povoljnu preraspodelu. Kombinovano razmatranje gore pomenutih faza analize zaostalih napona je dovelo do nastanka takozvanog RSM koncepta (kontrolisanje zaostalih napona)[3]. Ovaj koncept obuhvata sledeće glavne faze:

\section{Faza 1: Određivanje zaostalih napona.}

Faza 2: Aanliza uticaja zaostalih napona. Uticaj zaostalih napona se može oceniti bilo eksperimentalnim, bilo računskim metodama.

Faza 3: Modifikacija zaostalih napona (ukoliko je potrebna). Modifikacija zaostalih napona se može izvršiti promenama tehnologije proizvodnje/sklapanja i/ili primenom tehnika za rasterećenje zaostalih napona.

$\mathrm{U}$ poslednje vreme je razvijen veliki broj naprednih inženjerskih alata za sve tri faze RSM, od strane kopmanije Sintec Inc (Markam, Kanada). Pregled ovih novih inženjerskih alata za kontrolu zaostalih napona i primeri njihove praktične primene su prikazani ispod.

\section{Određivanje zaostalih napona}

Naponi se mogu odrediti direktno, merenjem primenom metoda sa ili bez razaranja, ili preko proračuna. Tokom poslednjih par decenija, raznovrsne kvalitativne i kvantitativne metoda sa i bez razaranja su razvijene sa ciljem merenja zaostalih napona [4]. Uopšteno, razlikuju se tehnike sa razarenjm i tehnike bez razaranja.

Prva grupa metoda je zasnovana na razaranju ravnotežnog stanja zaostalih napona nakon isecanja epruveta, mašinske obrade, skidanja slojeva ili bušenja rupa. Preraspodela unutrašnjih sila dovodi do pojave lokalnih deformacija, koje se mere kako bi se odredilo polje zaostalih napona. Zaostali napon se potom oduzima od izmerene deformacije, primenom teorije elastičnosti (analitičkim pristupom ili metodom konačnih elemenata).

Druga grupa metoda je zasnovana na merenju bez razaranja, koje se zasniva na poznavanju veza između fizičkih i kristalografskih parametara i zaostalih napona. Tehnika razvijena pod imenom ITL je zasnovana na primeni ultrazvuka. Ovaj pristup se oslanja na varijacije u brzini ultrazvučnih 
residual stress. The technique developed at ITL is based on the use of ultrasound. In this approach the variations in the velocity of ultrasonic wave propagation in the materials under the action of mechanical stresses are measured.

However, new industrial problems, new geometrical and material complexities related to them, combined with a general need for fast and economical residual stress measurements create strong demand in new effective techniques and devices. The most desired technology must be reliable and user-friendly, i.e. it should not require guessing and intuition from the engineer/technician and it must be computerized for quick analysis. The demand for sophisticated systems is increasing dramatically.

\subsection{Measurement of Residual Stresses by Ultrasonic Method}

The measurements of residual stresses (RS) by UltraMARS ${ }^{\circ}$ are based on solid theory, original technique and use of precise instrumentation. It is possible to use ultrasound for measurement of stresses in materials, because, according to the acousto-elastic theory of interaction of ultrasound with materials, the changes in travel velocities (or frequencies) of ultrasound in a material depend linearly on the stresses in the materials over a certain range of stresses.

For measurement of RS in parts, welded elements and structures, as a prerequisite, the determination of acousticelastic coefficients of the considered material has to be performed that is based on measurement of ultrasonic wave velocities in the sample under different known loadings and calculation of the acousto-elastic coefficients, based on these measurements. Once the acousto-elastic coefficients are determined, they are added to the UItraMARS $\AA$ device microprocessor for further computation of RS.

\subsection{Determination of Acousto-elastic Coefficients}

The samples for determination of acousto-elastic coefficients can be loaded in compression or in tension. Depending on the loading scheme the geometry of the sample is selected. Thus, for instance, a small sample, cut as shown in Fig.1, can be used for measurements of ultrasonic velocities in compression mode. talasa koji se prostiru u materijalu, koji je izložen mehaničkim naponima.

Međutim, novi problemi koji se javljaju u industriji, nove geometrijske i materijalne složenosti vezane za njih, u kombinaciji sa opštom potrebom za brzim i ekonomičnim merenjem zaostalih napona su doveli do povećanog zahtev za razvojem novih efikasnih tehnika i aparata. Najpoželjnija bi bila tehnika koja je puzdana i laka za primenu, tj. tehnika koja ne zahteva nagađanje i intuiciju od strane tehničara/inženjera i koja mora biti kompjuterizovana u ime brže analize. Zahtev za ovakve napredne sisteme dramatično raste.

\subsection{Merenje zaostalih napona ultrazvučnom metodom}

Merenje zaostalih napona (ZN) primenom UltraMARS ${ }^{\circ}$ metode je zasnovano na čvrstoj teorijskoj osnovi, originalnoj tehnici i primeni preciznih instrumenata. Moguće je koristiti ultrazvuk za merenje napona u materijalima usled dobro poznatog svojstva ultravzuka da, prema akustičnoelastičnoj teoriji interakcije, linearno menja brzinu (ili frekvenciju) u materijalu u zavisnosti od napona, u određenom rasponu.

U slučaju merenja $\mathrm{ZN} \mathrm{u}$ delovima, zavarenim elementima i konstrukcijama, određivanje akustično-elastičnih koeficijenata za predmetni material je preduslov, i mora se izvršiti na osnovu merenja brzina ultrazvučnih talasa u uzorku pod različitim poznatim opterećenjima. Na osnovu ovih merenja se određuju akustično-elastični koeficijenti, i nakon njihovog određivanja se unose u UltraMARS $₫$ apparat (mikroprocesor), kako bi se proračun zaostalih napona nastavio.

\section{$2.2 \quad$ Određivanje koeficijenata \\ akustično-elastičnih}

Uzorci za određivanje akustično-elastičnih koeficijenata se mogu opteretiti na pritisak ili zatezanje. U zavisnosti od vrste opterećenja se bira geometrija uzorka. Stoga, na primer, mali uzorak isečen kao na Slici 1 , može da se koristi za merenje ultrazvučnih brzina pri pritisnom opterećenju. 


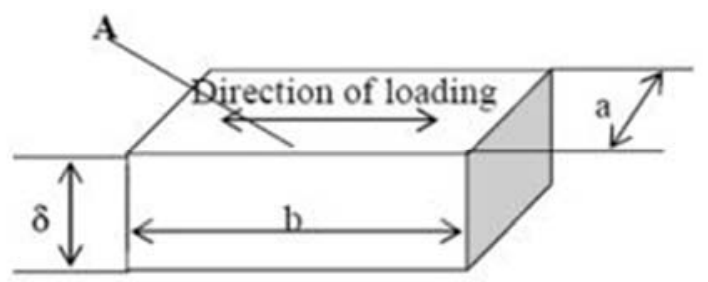

Figure 1. Schematic presentation of a sample prepared for determination of the acoustic-elastic coefficients of considered material: $a=50-60 \mathrm{~mm} ; b=70-80 \mathrm{~mm} ; \delta$ - thickness of considered material; $A-$ zone of installation of ultrasonic gauge(s) during loading of sample.

Slika 1. Šematski prikaz uzorka pripremljenog za određivanje akustično-elastičnih koeficijenata posmatranog materijala: $a=50-60 \mathrm{~mm} ; b=70-80 \mathrm{~mm} ; \delta$ - debljina materijala; $A$ - zona instalacije ultrazvučnih traka tokom opterećivanja uzorka.

An example of such a sample mounted for compressive loading in a tensile system is shown in Fig. 2. It is enough to perform the determination of acoustic-elastic coefficients on only one type of sample for follow up measurements and computation of both tensile and compressive residual stresses.
Primer jednog ovakvog uzorka izloženog pritisnom opterećenju na kidalici je prikazan na Slici 2. Ovo je dovoljno da se odrede akustično-elastični koeficijenti samo u jednom tipu uzoraka, koji će se koristiti pri narednim merenjima i proračunima, kako za pritisne, tako i za zatezne zaostale napone.

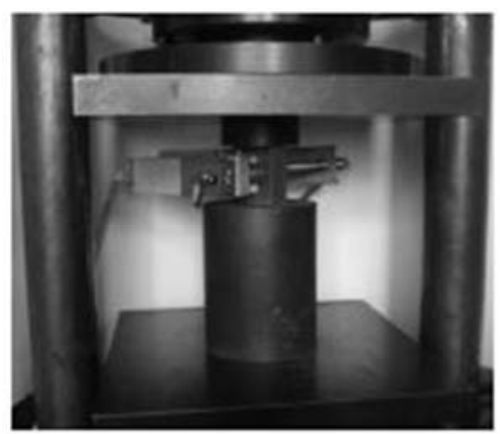

Figure 2. General view of the small sample loading set-up in a press

Slika 2. Opšti prikaz malog uzorka postavljenog u presi.

Fig. 3 presents the results of measurements of frequency changes in three ultrasonic signals, i.e. the longitudinal wave and two shear orthogonally polarized waves that were conducted at no load and at two compressive loads of - $150 \mathrm{MPa}$ and $300 \mathrm{MPa}$.
Na Slici 3 je prikazan rezultat merenja promene frekvencije u tri ultrazvučna signala, jednom podužnom i dva smičuća ortogonalno polarizovana talasa koji su pušteni bez opterećenja i pri pritisnim opterećenjima od -150 i $-300 \mathrm{MPa}$.

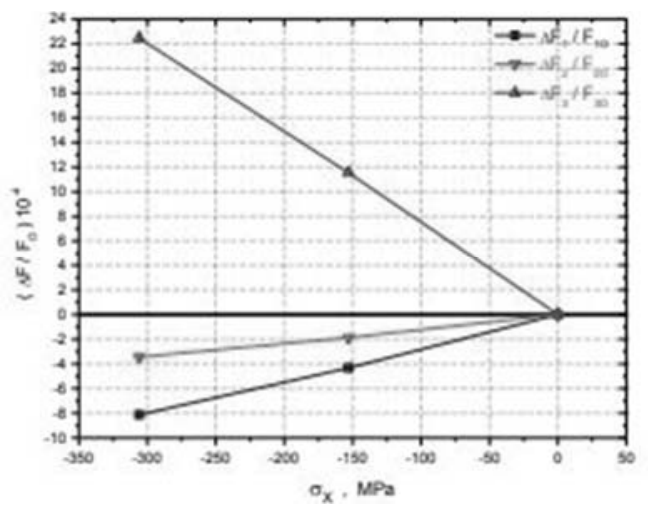

Figure 3. Changes of ultrasonic wave velocities in the sample of considered material under the action of applied stresses

Slika 3. Promene brzine ultrazvučnih talasa u uzorku posmatranog materijala pod delujućim opterećenjem 


\subsection{Examples of Residual Stress measurements with Bulk, Surface and Subsurface}

Transducers A butt welded sample, as shown in Fig. 4, with dimensions $200 \times 150 \mathrm{~mm}$ and $12 \mathrm{~mm}$ thick was used for residual stress measurements. The distribution of the longitudinal and transverse residual stresses (respectively, parallel and perpendicular to the weld direction) were measured along Lines 1-1 - 1-4, as marked in Fig. 4. The stresses were measured starting from point 1 (as marked in Fig. 4) and advancing towards point marked as $\mathrm{N}$.

The measurement point \#1 on vertical lines 1-1 and 1-3 was located at a distance of $\sim 3 \mathrm{~mm}$ from the weld toe. All measurements along horizontal lines 1-2 and 1-4 were made at a distance of $\sim 5$ $\mathrm{mm}$ from the weld toe. In general, ultrasonic measurements of residual stresses closer to the weld/bead or in the weld are possible, but require special preparation of surface of the weld/bead or removing of the weld reinforcement.

\subsection{Primeri merenja zaostalih napona primenom zapreminskih, površinskih i podpovršinskih sondi}

Ugaoni za vareni spoj prikazan na Slici 4, dimenzija 200x150 mm i debljine $12 \mathrm{~mm}$ je korišćen za merenje zaostalih napona. Raspodela podužnih i poprečnih zaostalih napona (paralelnih i upravnih na pravac zavarivanje, respektivno) je merena duž linija 1-1 - 1-4, kao što je obeleženo na slici. Naponi su mereni od početne tačke 1 (Slika 4), u pravcu tačke obeležene sa $\mathrm{N}$.

Merna tačka \#1 na vertikalnim linijama 1-1 i 1-3 se nalazi na rastojanju od $\sim 3 \mathrm{~mm}$ od zavarenog spoja. Sva merenja duž horizontalnih linija 1-2 i 1-4 su izvršena na udaljenosti od $\sim 5 \mathrm{~mm}$ od zavarenog spoja. Uopšteno, ultrazvučno merenje zaostalih napona u neposrednoj blizini zavarenog spoja je moguće, ali zahteva posebnu pripremu površine zavara ili uklanjanje njenog dela.

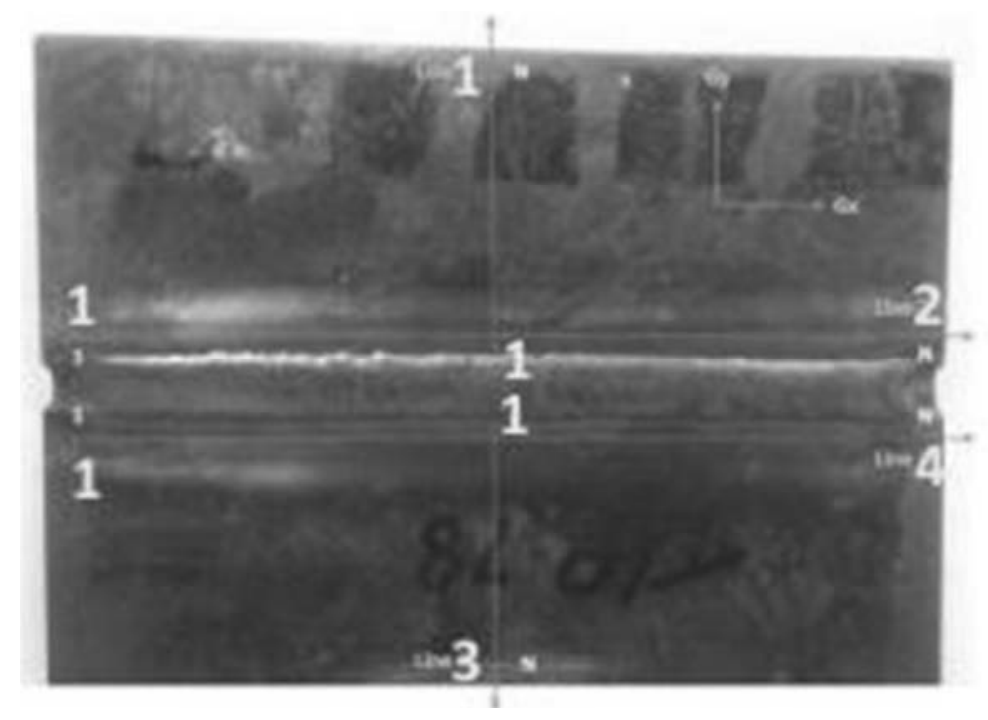

Figure 4. Welded sample (low carbon steel) with lines 1 - 4 marked on it that indicate the locations where the RS were measured

Slika 4. Zavareni uzorak (niskougljenični čelik) sa obeleženim linijama 1 - 4, koje označavaju mesta gde su ZN mereni

The longitudinal and transverse residual stresses (respectively parallel and perpendicular to the weld direction) were measured in the sample in each point with three types of ultrasonic transducers (Fig. 5), i.e. for recording the average through thickness (bulk) ultrasonic waves, the surface ultrasonic waves and the subsurface ultrasonic waves. Using the bulk ultrasonic waves allows measuring average through thickness residual stresses. Standard bulk transducers, with an active area of $10 \times 10 \mathrm{~mm}$ were used in these measurements (Fig. 5a).
Podužni i poprečni zaostali naponi (paralelni i upravni na pravac zavarivanja, respektivno) su mereni u svakoj tački na uzorku korišćenjem tri vrste ultrazvučnih sondi (Slika 5), tj. zapreminskim (za merenje po debljini), površinskim i podpovršinskim ultrazvučnim talasima. Primena zapreminskih ultrazvučnih talasa omogućava merenje prosečnih vrednosti zaostalih napona kroz celu debljinu. Standardne zapreminske sonde, sa aktivnom površinom $10 \times 10 \mathrm{~mm}$ su korišćeni za ovo merenje (Slika 5a). 


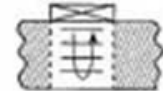

a

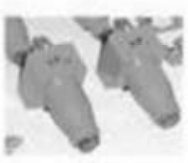

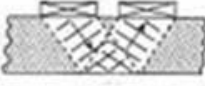

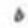

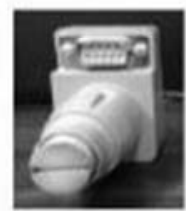

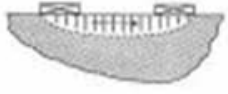

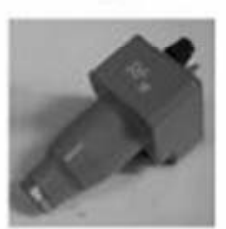

Figure 5. Schematic presentation and examples of transducers for ultrasonic measurement configurations: (a) through-thickness pulse-echo used for bulk, average through thickness stresses, (b) through-thickness pitch-catch that was set for sub-surface measurements and (c) surface pitch-catch used for surface residual stresses.

Slika 5. Šematski prikaz i primeri konfiguracija sondi za ultrazvučno merenje: (a) Puls-eho sonda za zapreminsko merenje zaostalih napona kroz celu debljinu, (b) $T$-R sonda za podpovršinsko merenje i merenje po debljini, (c) površinska $T-R$ sonda

Fig. 6 through Fig. 8 present the measurement results of residual stresses along lines 1-1 and 1-2 for all three types of transducers, i.e. bulk, surface and subsurface. Thus, Fig. $6 a$ and Fig. $6 \mathrm{~b}$ show the results from measurements of the bulk stresses along lines 1-1 and 1-2. In all cases two components of the residuals stress, $\sigma 22$ and $\sigma 33$ were measured (marked in the figures as $\sigma x$ and $\sigma y)$.

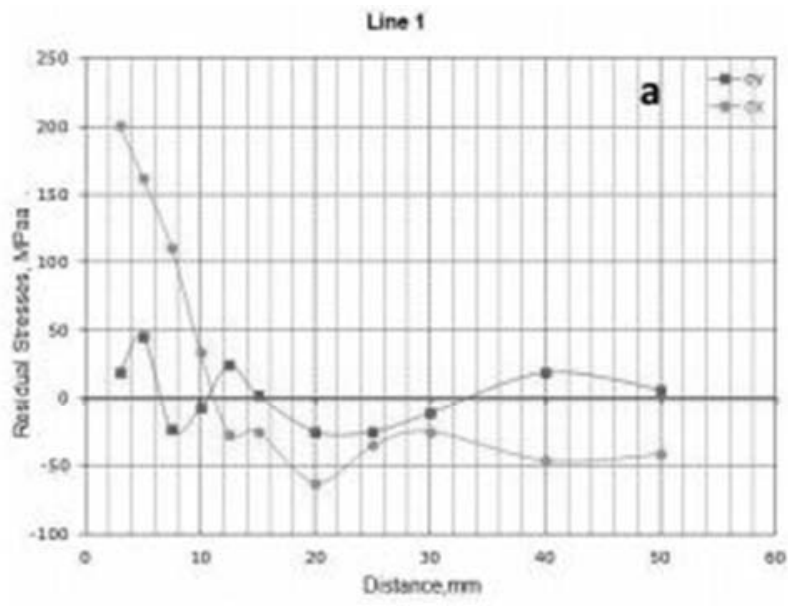

Na slikama 6-8 su prikazani rezultati merenja zaostalih napona duž linija 1-1 i 1-2, za sva tri tipa sondi (zapreminska, podpovršinska i površinska). Slike $6 a$ i $6 b$ prikazuju rezultate merenja zapreminskih napona duž linija 1-1 i 1-2. U svim slučajevima su merene dve komponente zaostalih napona, $\sigma_{22}$ i $\sigma_{33}$ (na slika obeležene kao $\sigma_{\mathrm{x}}$ i $\sigma_{\mathrm{y}}$ ).

Figure 6. (a) The distribution of residual stresses in the sample along Line 1-1. Bulk ultrasonic waves; (b) The distribution of residual stresses in sample along Line 1-2. Bulk ultrasonic waves.

Slika 6. (a) Raspodela zaostalih napona u uzorcima duž linije 1-1. Zapreminski ultrazvučni talasi; (b) Raspodela zaostalih napona duž linije 1-2. Zapreminski ultrazvučni talasi.

Fig. 7a and Fig. 7b present data measured using surface and subsurface transducers along line 1-1. Fig. $8 a$ and Fig. $8 b$ show similar data that was measured along line 1- 2.

The obtained RS profiles were analyzed and the obtained data had shown that the results of ultrasonic RS measurements in the sample are in accordance with existing understanding of the distribution of RS in welded elements and structures.
Slike $7 \mathrm{a}$ i $7 \mathrm{~b}$ prikazuju rezultate merenja pomoću podpovršinskih i površinskih sondi duž linije $1-1$, dok slike $8 a$ i $8 b$ prikazuju rezultate merenja duž linije 1-2.

Dobijeni profili ZN su analizirani i dobijeni podaci su pokazali da su rezultati ultrazvučnog ispitivanja ZN u skladu sa postojećim znanjem o raspodeli ZN u zavarenim spojevima i konstrukcijama. 
The $7 \times 4 \mathrm{~mm}$ standard surface transducer was used to measure residual stresses in surface layers of the sample material (Fig. 5c). The experimentally determined depth of penetration of ultrasonic signal (maximum depth of detected/measured signal) for this case was $\sim 0.7 \mathrm{~mm}$.

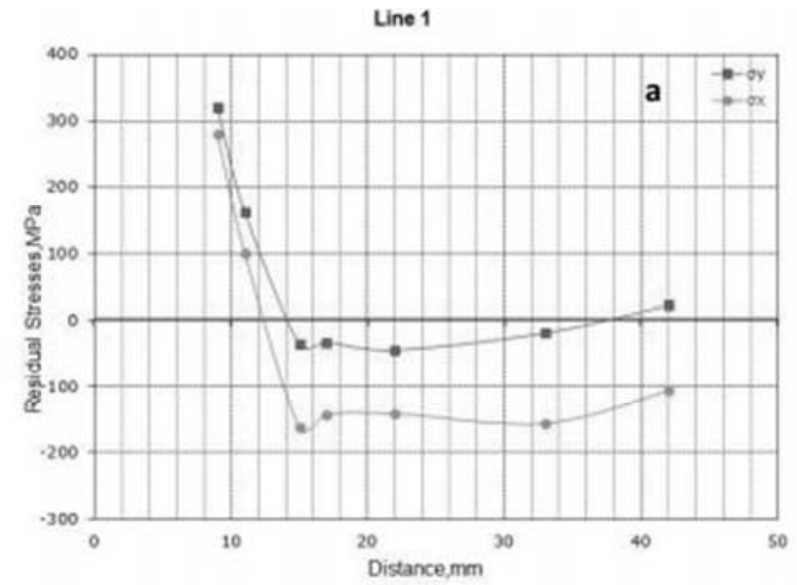

Standardna površinska sonda $7 \times 4 \mathrm{~mm}$ je korišćena za merenje zaostalih napona u površinskim slojevima uzorka materijala (Slika 5c). Eksperimentalno određena dubina penetracije ultrazvučnog signala (maksimalna dubina detektovanog/izmerenog signala) u ovom slučaju je iznosila $\sim 0.7 \mathrm{~mm}$.

Line 1

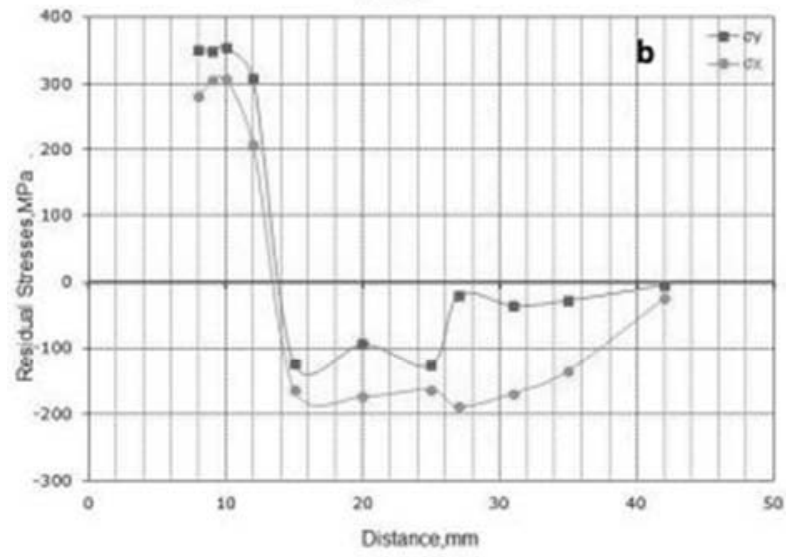

Figure 7. Distribution of residual stresses in surface and subsurface layers in the sample shown in Fig. 4.

(a) Residual stresses in sample along Line 1-1. Surface ultrasonic waves; (b) Residual stresses in sample along Line 1-1. Subsurface ultrasonic waves.

Slika 7. Raspodela zaostalih napona na površini i ispod površine u uzorku sa slike 4. (a) Zaostali naponi duž linije 11. Površinski ultrazvučni talasi (b) Zaostali naponi duž linije 1-1. Podpovršinski ultrazvučni talasi

The experimentally determined depth of penetration of the ultrasound signal for the case of subsurface measurements reached $2.4 \mathrm{~mm}$. The $7 \times 4 \mathrm{~mm}$ standard transducer was selected for this application (Fig. 5b). In general, it should be noted that by using subsurface transducers, it is possible to measure stresses to a depth of $3-10 \mathrm{~mm}$ and more.

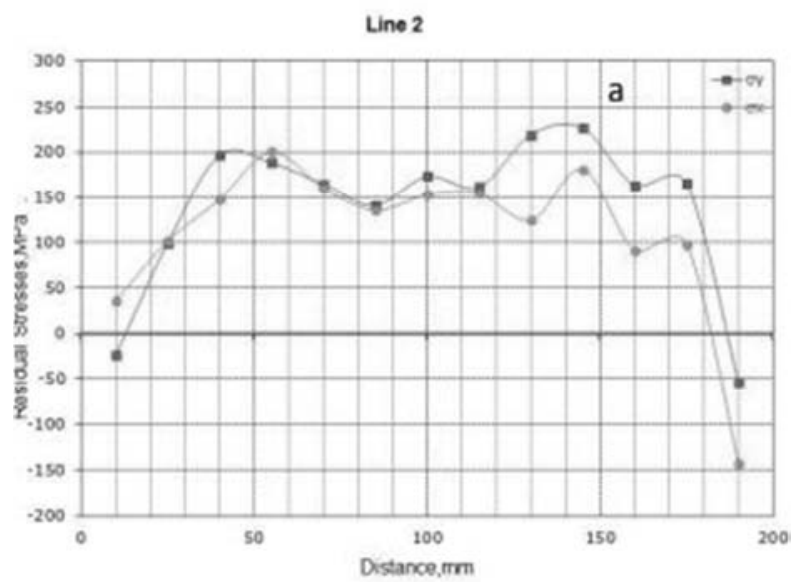

Eksperimentalno određena dubina penetracija ultrazvučnog signala u slučaju podpovršinskog merenja je iznosila $2.4 \mathrm{~mm}$. Standardna sonda $7 \times 4$ $\mathrm{mm}$ je izabrana za ovu svrhu (Slika $5 \mathrm{~b}$ ). Uopšteno, treba napomenuti da je primenom podpovršinskih sondi moguće meriti napone do dobine od 3-10 mm (ili više).

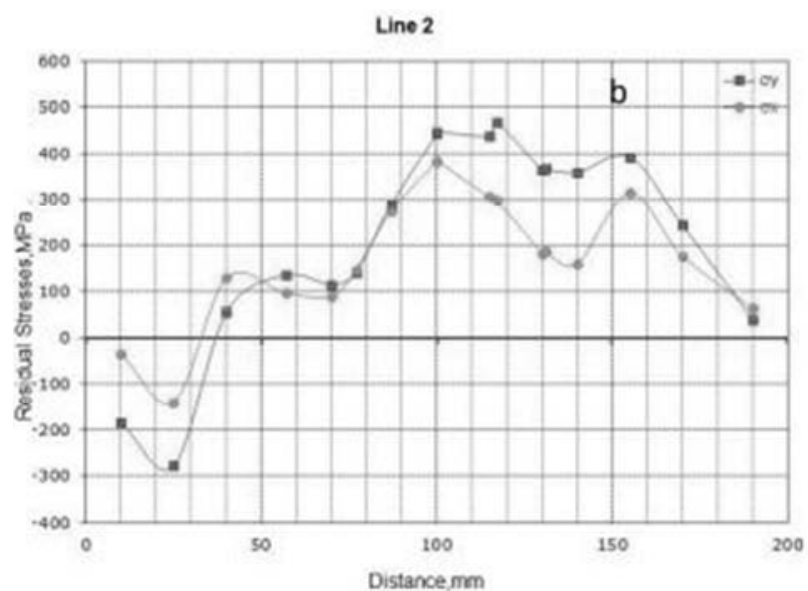

Figure 8. Distribution of residual stresses in surface and subsurface layers in the sample shown in Fig. 4. (a) Residual stresses in sample along Line 1-2 as measured with the surface transducer; (b) Residual stresses in sample along Line 1-2 as measured with the subsurface transducer

Slika 8. Raspodela zaostalih napona na površini i ispod površine u uzorku sa slike 4, (a) Zaostali naponi duž linije 12. Površinski ultrazvučni talasi (b) Zaostali naponi duž linije 1-12 Podpovršinski ultrazvučni talasi 


\subsection{Residual Stress Measurement System UltraMARS $尺$}

In general, the change in the ultrasonic wave velocity in structural materials under mechanical stress amounts only to tenths of a percentage point. Therefore, the equipment for practical application of ultrasonic technique for residual stress measurement should be of high resolution, reliable and fully computerized. The major parts of the developed system for residual stress analysis [5] ] - [[9] include a measurement unit with supporting software, a preamplifier with a magnetic, electromagnetic or mechanical holder and interchangeable transducers. For selection of the appropriate reflected wave and tuning in manual mode an oscilloscope is, usually, used (Fig. 9). The designed system allows determining uni- and biaxial applied and residual stresses for a wide range of materials and structures.

\subsection{Merenje zaostalih napona sistemom - UItraMARS $\circledR$}

Uopšteno, promena brzine ultrazvučnih talasa u konstrukcijskim materijala izloženim mehaničkim naponima se izražava u desetim delovima procenta. Stoga, oprema za praktičnu primenu ultrazvučne tehnike pri merenju zaostalih napona mora imati visoku rezoluciju, i da bude pouzdana i potpuno kompjuterizovana. Glavni delovi razvijenog sistema za analizu zaostalih napona [5-9] obuhvataju mernu jedinicu i njen prateći softver, predpojačalo sa magetnim, elektromagnetnim ili mehaničkim držačem i zamenljive sonde. Za izbor odgovarajućeg reflektovanog talasa se obično koristi ručno podešavanje i osciliskop (Slika 9.). Ovakav sistem omogućava određivanje jedno- i dvoosnih zaostalih napona za jako veliki broj materijala i konstrukcija.

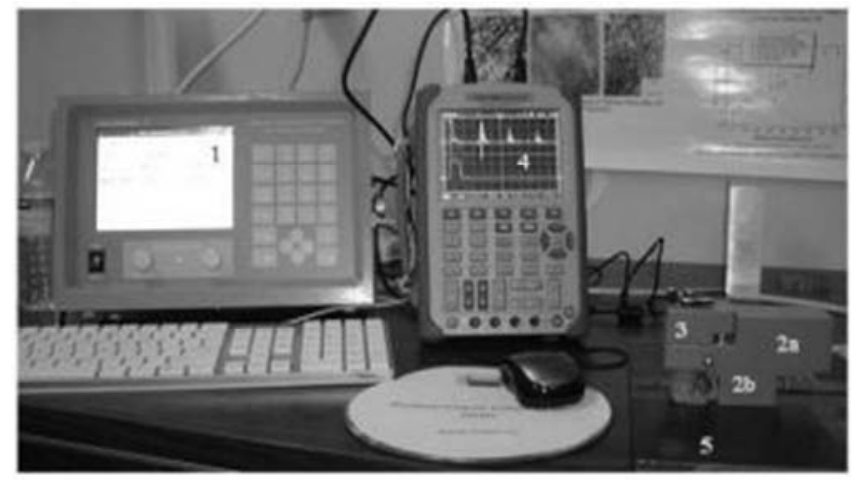

Figure 9. Ultrasonic Computerized Complex for residual and applied stress measurement. - Measurement unit UltraMARS with supporting software, (2a) - Preamplifier, (2b) - Magnetic holder, (3) - Transducer, (4) Oscilloscope, (5) - Sample.

Slika 9. Kompjuterizovani Ultrazvučni Kompleks za merenje delujućih i zaostalih napona. - Merna jedinica UltraMARS $®$ i njen prateći softver, (2a) - Predpojačalo, (2b) - Magnetni držač, (3) - Pretvarač, (4) - Osciloskop, (5) Uzorak.

The UltraMARS system also offers measurement of material thickness and their Young modulus and Poisson ratio.

\section{Analysis of the residual stress effects}

In general, in the modern standards and codes on fatigue design the data presented correspond to the fatigue strength of real welded joints including the effect of welding technology, type of welded element and welding residual stresses. Nevertheless, in many cases there is a need to consider the influence of welding residual stresses on the fatigue life of structural components in details. These cases include: the using of the results of fatigue testing of relatively small welded specimens without high tensile residual stresses, analysis of the effect of the such factors as
UltraMARS sistem takođe nudi mogućnost merenja debljine materijala, modula elastičnosti i Poasonovog koeficijenta.

\section{Analiza uticaja zaostalih napona}

Uopšteno, podaci dati u savremenim standardima i kodovima vezanim za zamor odgovaraju zamornoj čvrstoći stvarnih zavarenih konstrukcija, u koju ulaze i uticaji tehnologije zavarivanja, vrste zavarenog elementa i zaostali naponi pri zavarivanju. Međutim, u mnogim slučajevima je potrebno još detaljnije posmatrati uticaj ZN na zamorni vek komponenti. Ovi slučajevi obuhvataju: korišćenje rezultata zamornih ispitivanja na relativno male zavarene uzorke bez visokih zateznih zaostalih napona, analizu uticaja 
overloading, spectra loading, application of the improvement treatments etc.

An Expert System for Fatigue Assessment and Optimization of Welded Elements - RESIsT was developed to find the optimum way for fatigue life improvement of welded elements without the increase in metal consumption [10]. Major attention was paid to developing the predictive model for analysis of the influence of the residual stresses and their redistribution under the effect of cyclic loading and improvement treatments on the fatigue life of welded elements.

The following important parameters of welded elements with the goal to enhance the fatigue performance are analyzed:

- $\quad$ preferred design of welded elements;

- material selection and weld processes;

- welding residual stresses;

- application of the improvement treatments;

- influence of possible repair technologies;

- realistic service conditions.

The RESIsT includes the possibility to assess through calculations the effect of residual stresses and improvement treatments application on the fatigue life of welded elements without having the performing the time and labour consuming fatigue tests [11].

\section{Residual stress modification}

In 2010 Commission XIII of the International Institute of Welding (IIW) introduced the term high frequency mechanical impact (HFMI) as a generic term to describe several related surface treatment technologies. In addition to the ultrasonic sources, alternate power sources like compressed air may be employed [12]. The working principle in the HFMI treatments is similar, i.e. cylindrical indenters are accelerated against a component or structure and strike it with high frequency (>90 Hz), producing highly plastically deformed regions in the impacted material and causing changes in the material microstructure and the local geometry as well as the residual stress state in the region of impact. Differences exist, however, between the different HFMI devices that are presently on the market, among which the main is in the treatment frequency that covers a range from a few hundred to over thousand of $\mathrm{Hz}$. Usually, the higher the treatment frequency, the easier it is to control the tool and, consequently, the less is the operator's fatigue. faktora poput preopterećenja, spektra opterećenja, primenu obrade u cilju poboljšanja, itd.

Stručni Sistem za Ocenu Zamora i Optimizaciju Zavarenih Elementata - RESIsT je razvijen sa ciljem da se pronađe optimalni način produženja zamornog veka zavarenih elemenata bez povećane potrošnje metala [10]. Najveća pažnja je posvećena razvoju prediktivnog modela za analizu uticaja zaostalih napona i njihove preraspodele pod uticajem cikličnog opterećenja i obrade u cilju poboljšanja na zamorni vek zavarenih elemenata.

Sledeći važni parametri zavarenih elemenata će biti analizirani u cilju poboljšvanja ponašanja konstrukcije pod zamorom:

- Poželjan dizajn zavarenih elemenata

- Izbor materijala i postupka zavarivanja

- Zaostali naponi pri zavarivanju

- Primena obrade u cilju poboljšanja

- Uticaj potencijalnih tehnologija reparacije

- Stvarni radni uslovi

RESiST takođe omogućava i ocenu uticaja zaostalih napona preko proračuna, kao i poboljšanje zamornog veka zavarenih konstrukcija bez potrebe za izvođenjem zamornih ispitivanja koja zahtevaju mnogo vremena i napora [11].

\section{Modifikacija zaostalih napona}

$\mathrm{Na}$ Komisiji XIII Međunarodnog Instituta za Zavarivanje (International Welding Institute - IIW), 2010. godine je uvede termin visokofrekventni mehanički udar (high ferquency mechanical impact - HFMI), kao opšti termin za opisivanje nekoliko usko povezanih metoda površinske obrade. Pored ultrazvučnih izvora, mogu se koristiti i alternative, kao na primer komprimovani vazduh [12]. Princip rada HFMl obrade je veoma sličan, i zasniva se na visokofrekventnom (>90 Hz) udaranju ubrzanog cilindričnog čekića, usled čega nastaju veoma plastično deformisane oblasti u udarenom materijalu. Usled toga dolazi do značajnih promena u mikrostrukturi i lokalnoj geometriji, uz pojavu zaostalih napona u oblasti udara. Ipak, postoje razlike između raznih HFMI aparata koji su trenutno prisutni na tržištu, pre svega u pogledu frekvencije obrade, koja pokriva opseg od nekoliko stotina do nekoliko hiljada $\mathrm{Hz}$. U opštem slučaju, što je viša frekvencija obrade, to je lakše kontrolisati alat, što za posledicu ima manji zamor operatera. 


\subsection{Ultrasonic Impact Treatment}

The ultrasonic impact treatment (UIT) [1], [13] [17] that in most industrial applications is also known as ultrasonic peening (UP) [18] - [20] is gaining worldwide acceptance as one of the new and promising processes for fatigue life improvement of welded elements and structures. The beneficial effect of UP is achieved mainly by relieving of harmful tensile residual stresses and introducing of compressive residual stresses into surface layers of materials, decreasing of stress concentration in weld toe zones and enhancement of mechanical properties of the surface layers of the material.

The fatigue testing of welded specimens showed that the UP is the most efficient improvement treatment when compared with such traditional techniques as grinding, TIG-dressing, heat treatment, hammer peening, shot peening and application of low temperature transformation (LTT) electrodes [1], [23], [24].

The UP technique is based on the combined effect of high frequency impacts of special strikers and ultrasonic oscillations in treated material. A number of basic units for different application were developed to include treatments in air and underwater (Fig. 10) [25].

All systems are designed based on "Power on Demand" concept. Using this concept, the power and other operating parameters of the UP equipment are adjusted to produce the necessary changes in residual stresses, stress concentration and mechanical properties of the surface layers of materials to attain the maximum possible increase in fatigue life of welded elements and structures.

\subsection{Obrada ultrazvučnim udarom}

Obrada ultrazvučnim udarom (Ultrasonic impact treatment - UIT) [1, 13-17], u većini industrija poznata pod nazivom ultrazvučno sačmarenje (ultrasonic peening - UP), [18-20] postaje opšteprihvaćena kao novi i obećavajuć proces vezan za produženje zamornog veka zavarenih elemenata i konstrukcija. Svoj koristan efekat UP ostvaruje pre svega rasterećenjem opasnih zateznih zaostalih napona i uvođenjem pritisnih ZN u površsinke slojeve materijala, čime se smanjuje koncentracija napona u oblasti linije stapanja i poboljšavaju se mehaničke osobine površinskog sloja materijala.

Zamorno ispitivanje zavarenih uzoraka je pokazalo da je UP najefikasnija metoda obrade $u$ poređenju sa drugim tradicionalnim tehnikama, poput brušenja, TIG oblaganja, termičke obrade, čekićanja, klasičnog sačmarenja i primene niskotemperaturne transformacije (low-temperature transformation - LTT) [1, 23, 24].

UP tehnika je zasnovana na kombinovanom uticaju visokofrekventnog udara specijalnim čekićima i ultrazvučnih oscilacija u obrađenom materijalu. Veliki broj osnovnih jedinica za različite vrste primena je razvijen kako bi se obuhvatile i obrade na vazduhu i pod vodom (Slika 10) [25].

Svi sistemi su konstruisani na osnovu koncepta „Snaga po potrebi“. Primenom ovog koncepta, snaga i drugi radni parametri UP opreme se prilagođavaju kako bi se ostvarile neophodne promene zaostalih napona, koncentracije napona i mehaničkih osobina površinskih slojeva materijala, čime se postiže maksimalno produženje zamornog veka zavarenih elemenata i konstrukcija.

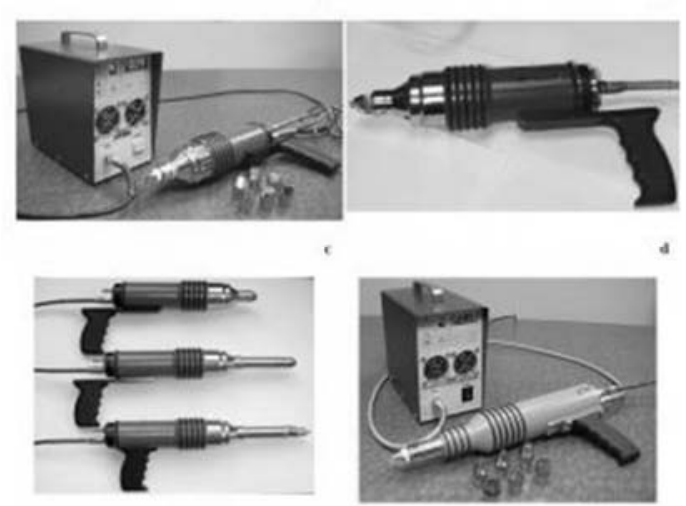

Figure 10. Ultrasonic peening systems for fatigue life improvement of welded elements and structures. a) UP-600 Model; b) ultrasonic peening tool for underwater peening UP-600U; c) various modifications of the basic peening tool for UP-600; d) New ultrasonic peening system UP-700.

Slika 10. Sistemi za ultrazvučno sačmarenje za poboljšanje zamornog veka zavarenih elemenata $i$ konstrukcija. a) UP-600 Model; b) alat za podvodno sačmarenje UP-600U; c) različite modifikacije osnovnog alata za ultrazvučno sačmarenje UP-600, d) novi sistem UP-700 
All peening tools have replaceable interchangeable working heads that were developed based on the requirements in particular applications and that vary in geometry, shape and number of pins. Fig. 11 shows some of the designs of the interchangeable working heads.
Sav alat za sačmarenje ima zamenljive radne glave koje su razvijene prema zahtevima pojedinačnih primena $\mathrm{i}$ koje se razlikuju po geometriji, obliku i broju pinova. Na Slici 11 su prikazana neka od postojećih rešenja za zamenljive radne glave.
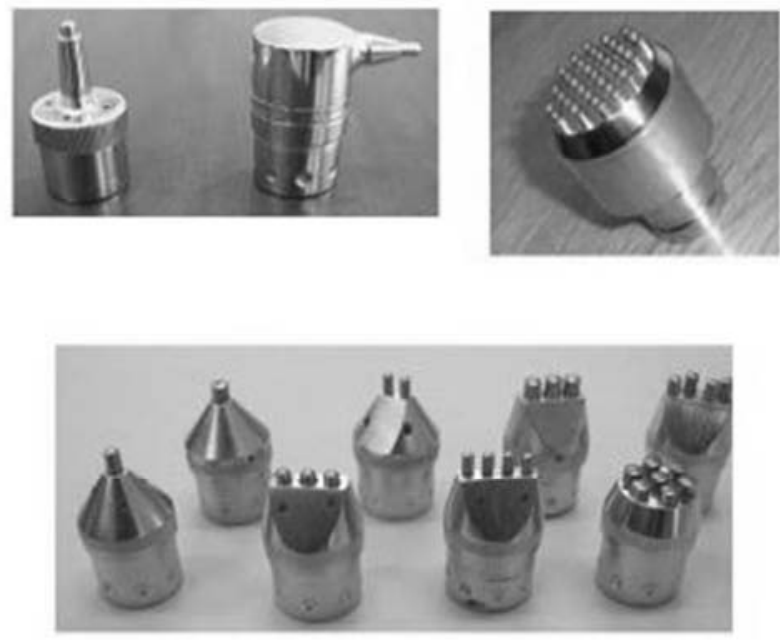

Figure 11. Examples of the replaceable interchangeable working heads developed for the ultrasonic peening of materials and structures.

Slika 11. Primeri zamenljivih radnih glava za optrebe ultrazvučnog sačmarenja materijala i konstrukcija

\subsection{Principles of Ultrasonic Peening Treatment}

In the fatigue improvement, the beneficial effect is achieved mainly by introducing of the compressive residual stresses into surface layers of metals and alloys, decrease in stress concentration in weld toe zones and the enhancement of the mechanical properties of the surface layer of the material. The schematic view of a cross section of a material/part improved by UP is shown in Fig. 12 with the attained distribution of the stresses after the UP. The description of the benefits that may be achieved after UP treatment is presented in Tab. 1.

\subsection{Primene obrade ultrazvučnim sačmarenjem}

U pogledu poboljšanja otpornosti na zamor, pozitivan efekat se ostvaruje pre svega uvođenjem pritisnih zaostalih napona u površinske slojeve metala i legura, smanjenjem koncentracije napona u oblasti zavarenog spoja i poboljšanjem mehaničkih osobina površinskog sloja materijala. Šematski prikaz preseka materijala/dela poboljšanog primenom UP se može videti na slici 12, zajedno sa dobijenom raspodelom napona nakon obrade. Opis prednosti koje se mogu ostvariti primenom ove metode je prikazan u tabeli 1.

Table 1. Zones of Material/Part Improved by Ultrasonic Peening (see Figure 12 for illustration of the zones)

Tabela 1. Zone materijala/delova koje su poboljšane UP metodom (vidi ilustraciju na slici 12).

\begin{tabular}{|c|c|c|c|}
\hline Zona & Description of zone/Opis zone & $\begin{array}{c}\text { Distance from } \\
\text { surface/ Udaljenost } \\
\text { of površine }\end{array}$ & $\begin{array}{c}\text { Improved characteristics/ } \\
\text { Unapređene osobine }\end{array}$ \\
\hline A & $\begin{array}{c}\text { Zone of plastic deformation and compressive } \\
\text { residual stresses/ } \\
\text { Zona plastične deformacije i pritisnih zoastalih } \\
\text { napona }\end{array}$ & $1-1,5 \mathrm{~mm}$ & $\begin{array}{c}\text { Fatigue/Zamor } \\
\text { Corrosion/Korozija } \\
\text { Wear/Habanje }\end{array}$ \\
\hline $\mathrm{B}$ & $\begin{array}{c}\text { Zone of relaxation of welding residual stresses/ } \\
\text { Zona relaksacije zaostalih napona pri zavarivanju }\end{array}$ & $15 \mathrm{~mm}$ i više & $\begin{array}{c}\text { Distortion/Distorzija } \\
\text { Crack propagation /Rast prsline }\end{array}$ \\
\hline $\mathrm{C}$ & $\begin{array}{c}\text { Zone of nanocrystallization(produced at certain } \\
\text { conditions)/Zona nanokaristalizacije (nastaje u } \\
\text { određenim uslovima) }\end{array}$ & $0.01-0.1 \mathrm{~mm}$ & $\begin{array}{c}\text { Corrosion//Korozija } \\
\text { Wear/Habanje } \\
\text { Fatigue at elevated } \\
\text { temperature/Zamor na } \\
\text { povišenim temperaturama }\end{array}$ \\
\hline
\end{tabular}




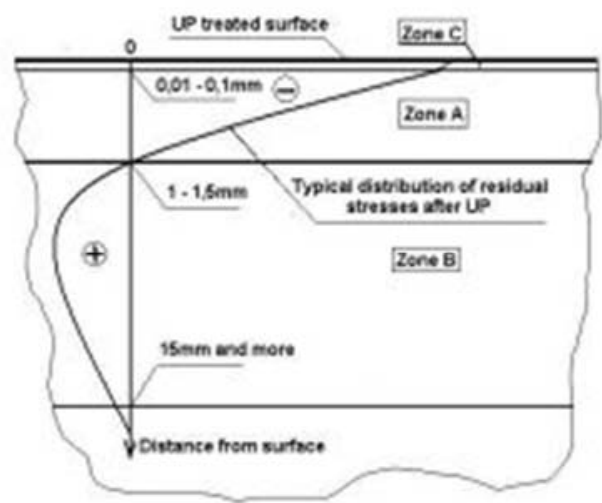

Figure 12. The distribution of residual stresses through thickness of a material/part improved by Ultrasonic Peening

Slika 12. Raspodela zaostalih napona po debljini materijala/delova poboljšanih primenom ultrazvučnog sačmarenja

\subsection{Ultrasonic Peening Treatment of Welded Structures}

Ultrasonic peening was applied successfully in mining industry to repair and rehabilitate welded elements subjected to fatigue loading. In an examples shown below, all welds in two large grinding mills (Fig. 13, left) used for iron ore crushing were treated by UP to increase the fatigue performance of the mills and to allow increasing the ore load (Fig. 13, right). About 300 meters of welds critical from fatigue point of view were UP treated on each of the mills to provide the improved fatigue performance. Only the weld toes on the shell plate side were treated in both, the longitudinal and circumferential welds.

\subsection{Obrada zavarenih konstrukcija ultrazvučnim sačmarenjem}

Ultrazvučno sačmarenje je uspešno primenjeno u rudarskoj industriji u cilju reparature i rehabilitacije zavarenih elemenata izloženih zamornom opterećenju. U primerima prikazanim ispod, svi zavareni spojevi u okviru dva velika mlina za mlevenje rude gvožđa (Slika 13, levo) su obrađena primenom UP, kako bi im se poboljšala otpornost na zamor, čime bi se omogućila prerada veće količine rude (Slika 13, desno). Oko 300 metara zavara koji su smatrani kritičnim, s tačke gledišta zamora su obrađene na ovaj način, kako bi im se poboljšala otpornost na zamor. Samo su linije stapanja obrađene u oba pravca, podužnom i poprečnom.
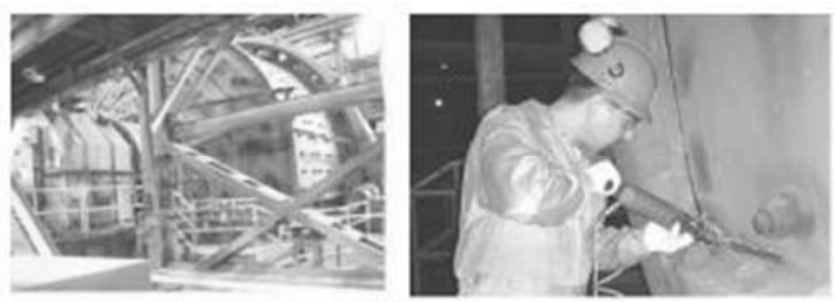

Figure 13. General view of one of the grinding mills that was treated by UP (left)) and application of UP for rehabilitation of a weldment region in the grinding mill (right).

Slika 13. Opšti prikaz jednog od mlinova za rudu gvožđa koji je obrađem primenom UP (levo) u cilju rehabilitacije zavarenih elemenata (desno).

A number of studies were conducted on use of UP for improvement of the fatigue life of different welded aluminium alloys [26] - [28]. Thus, in a study of the influence of UP on fatigue strength of overlapped welded $3 \mathrm{~mm}$ thick 6061-T6 aluminium alloy samples (Fig. 14a), two series of samples with joints with overlap sizes of $6 \mathrm{~mm}$ and $15 \mathrm{~mm}$ were MIG-Pulse welded and fatigue tested before and after UP treatment to estimate the influence of misalignment angle on fatigue of the welded joints.
Sproveden je veliki broj studija o primeni UP u poboljšavanju zamornog veka različitih zavarenih konstrukcija od aluminijuma [26-28]. U tu svrhu će biti prikazana studija o uticaju UP na zamornu čvrstoću preklopnog zavarenog spoja debljine 3 $\mathrm{mm}$, od aluminijumske legure 6061-T6 (Slika 14a), uz još dva uzorka sa preklopima od 6 i $15 \mathrm{~mm}$, koji su zavareni MIG-puls postupkom i ispitani na zamor pre obrade ultrazvučnim sačmarenjem, kako bi se ispitao uticaj ugla smaknuća.

-Kraj 1. dela NASTAVAK U SLEDEĆEM BROJU 